\title{
Commentary: Escape valve for the pressures of life
}

\author{
Tomasz A. Timek, MD, PhD
}

\footnotetext{
From the Division of Cardiothoracic Surgery, Spectrum Health, Grand Rapids, Mich; and Michigan State University College of Human Medicine, Grand Rapids, Mich.

Disclosures: Author has nothing to disclose with regard to commercial support.

Received for publication Sept 3, 2019; revisions received Sept 3, 2019; accepted for publication Sept 3, 2019; available ahead of print Sept 20, 2019.

Address for reprints: Tomasz A. Timek, MD, PhD, Division of Cardiothoracic Surgery, Spectrum Health, Michigan State University College of Human Medicine, 100 Michigan Ave NE, Grand Rapids, MI 49503 (E-mail: tomasz.timek@spectrumhealth.org).

J Thorac Cardiovasc Surg 2020;160:e129-30

$0022-5223 / \$ 36.00$

Copyright (C) 2019 by The American Association for Thoracic Surgery

https://doi.org/10.1016/j.jtcvs.2019.09.006
}

Ischemic mitral regurgitation (IMR) continues to be a clinical enigma with suboptimal surgical results ${ }^{1}$ and poor long-term outcomes. ${ }^{2}$ The interplay between myocardial infarction, ventricular remodeling, and valvular incompetence has been studied extensively, yet no clear picture emerges as to whether mitral insufficiency is an underlying cause or a marker of ventricular remodeling and poor prognosis. Previous studies in sheep have suggested that elimination of IMR does not alter ventricular remodeling, ${ }^{3}$ yet timing of intervention might be of critical importance. ${ }^{4,5}$ In this issue of The Journal of Thoracic and Cardiovascular Surgery, Onohara and colleagues ${ }^{6}$ present a rodent model of structural mitral regurgitation (MR) and myocardial infarction to study the effect of each intervention in isolation and their additive effect on chamber remodeling and myocardial function. This is an elegant study with advanced imaging and invasive monitoring techniques that are not easily achieved in small animals. The authors report that severe structural MR when induced in the setting of anterior left ventricular ischemia results in greater chamber remodeling then either isolated infarction or valvular insufficiency. These results suggest that elimination of mitral insufficiency in ischemic ventricles might favorably affect chamber remodeling and myocardial function, but extrapolation of these data to the surgical treatment of ischemic MR should be made with caution.

An analogous model of controlled leaflet perforation in sheep ${ }^{7}$ similarly revealed significant end systolic and end diastolic volume increase 12 weeks after induction of MR, confirming the authors' findings in a large animal model. The observed chamber remodeling with this form of structural MR was reported to be associated with abnormal torsional dynamics ${ }^{8}$ and altered transmural myocardial strain. ${ }^{9}$ IMR, however, develops over time after an initial posterolateral myocardial infarction which is not immediately associated with significant valvular insufficiency. ${ }^{10}$ In the current study, the authors induced left ventricular ischemia and concurrent severe structural

\section{References}

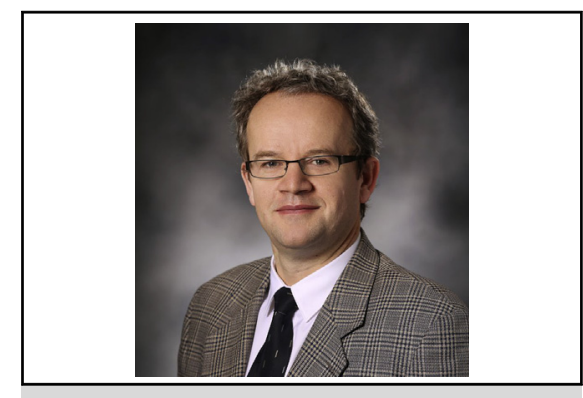

Tomasz A. Timek, MD, PhD

Central Message

Mitral regurgitation adversely influences chamber remodeling in the setting left ventricular infarction.

See Article page e107.

MR, potentiating their effect on chamber remodeling to a degree that might not be seen clinically. Although the authors elegantly demonstrate the additive effect of ischemia and MR on left ventricular function and remodeling, the evolution of ischemic MR is more complex than the sum of its individual parts. In clinical studies, when left ventricular end diastolic diameter reaches $65 \mathrm{~mm}$ correction of severe $\mathrm{IMR}^{11}$ does not improve clinical outcomes suggesting the "horse is out of the barn," and earlier intervention should be considered. However, surgical treatment of less than severe MR at the time of concurrent coronary artery bypass grafting has not been shown to affect chamber remodeling or mortality in the short term. ${ }^{12}$ Recent analysis of randomized trials of percutaneous treatment of IMR has implicated the equilibrium between degree of valvular insufficiency and chamber remodeling as a guide for effective surgical therapy of IMR. ${ }^{13}$ The presented experimental data add scientific scaffolds to these emerging concepts and such rigorous efforts will pave the path to effective surgical therapy. Whether the mitral insufficiency is an integral component of the pathophysiology of postinfarct chamber remodeling or a "pop-off" valve for the distressed left ventricle remains to determined.

1. Goldstein D, Moskowitz AJ, Gelijns AC, Ailawadi G, Parides MK, Perrault LP, et al. Two-year outcomes of surgical treatment of severe ischemic mitral regurgitation. $N$ Engl J Med. 2016;374:344-53.

2. Mihaljevic T, Lam BK, Rajeswaran J, Takagaki M, Lauer MS, Gillinov AM, et al. Impact of mitral valve annuloplasty combined with revascularization in patients 
with functional ischemic mitral regurgitation. J Am Coll Cardiol. 2007;49: 2191-201.

3. Matsuzaki K, Morita M, Hamamoto H, Noma M, Robb JD, Gillespie MJ, et al. Elimination of ischemic mitral regurgitation does not alter long-term left ventricular remodeling in the ovine model. Ann Thorac Surg. 2010;90:78.

4. Beaudoin J, Levine RA, Guerrero JL, Yosefy C, Sullivan S, Abedat S, et al Late repair of ischemic mitral regurgitation does not prevent left ventricular remodeling: importance of timing for beneficial repair. Circulation. 2013;128: S248-52.8-94.

5. Beeri R, Yosefy C, Guerrero JL, Abedat S, Handschumacher MD, Stroud RE, et al. Early repair of moderate ischemic mitral regurgitation reverses left ventricular remodeling: a functional and molecular study. Circulation. 2007; 116:I288-93.

6. Onohara D, Corporan D, Hernandez-Merlo R, Guyton RA, Padala M. Mitral regurgitation worsens cardiac remodeling in ischemic cardiomyopathy in an experimental model. J Thorac Cardiovasc Surg. 2020;160:e107-25.

7. Nguyen TC, Itoh A, Carlhäll CJ, Bothe W, Timek TA, Ennis DB, et al. The effect of pure mitral regurgitation on mitral annular geometry and three-dimensional saddle shape. J Thorac Cardiovasc Surg. 2008;136: 557-65.
8. Ennis DB, Nguyen TC, Itoh A, Bothe W, Liang DH, Ingels NB, et al. Reduced systolic torsion in chronic "pure" mitral regurgitation. Circ Cardiovasc Imaging. 2009;2:85-92.

9. Carlhäll CJ, Nguyen TC, Itoh A, Ennis DB, Bothe W, Liang D, et al. Alterations in transmural myocardial strain: an early marker of left ventricular dysfunction in mitral regurgitation? Circulation. 2008;118(14 suppl):S256-62.

10. Llaneras MR, Nance ML, Streicher JT, Linden PL, Downing SW, Lima JA, et al. Pathogenesis of ischemic mitral insufficiency. J Thorac Cardiovasc Surg. 1993; 105:439-42.

11. Braun J, Bax JJ, Versteegh MI, Voigt PG, Holman ER, Klautz RJ, et al. Preoperative left ventricular dimensions predict reverse remodeling following restrictive mitral annuloplasty in ischemic mitral regurgitation. Eur J Cardiothorac Surg. 2005;27:847-53.

12. Michler RE, Smith PK, Parides MK, Ailawadi G, Thourani V, Mozkowitz AJ, et al. Two-year outcomes of surgical treatment of moderate ischemic mitral regurgitation. N Engl J Med. 2016;374:1932-41.

13. Grayburn PA, Sannino A, Packer M. Proportionate and Disproportionate Functional Mitral Regurgitation: A New Conceptual Framework That Reconciles the Results of the MITRA-FR and COAPT Trials. JACC Cardiovasc Imaging. 2019;12:353-62. 